University of New Hampshire

University of New Hampshire Scholars' Repository

9-1994

\title{
Climatic, edaphic, and biotic controls over storage and turnover of carbon in soils
}

\author{
David S. Schimel \\ NCAR \\ Rob Braswell \\ University of New Hampshire - Main Campus, rob.braswell@unh.edu \\ Elisabeth A. Holland \\ NCAR \\ R McKeown \\ NCAR
}

Dennis S. Ojima

The H. John Heinz III Center for Science, Economics, and the Environment, Washington, DC

See next page for additional authors

Follow this and additional works at: https://scholars.unh.edu/earthsci_facpub

\section{Recommended Citation}

Schimel, D. S., B. H. Braswell, E. A. Holland, R. McKeown, D. S. Ojima, T. H. Painter, W. J. Parton, and A. R. Townsend (1994), Climatic, edaphic, and biotic controls over storage and turnover of carbon in soils, Global Biogeochem. Cycles, 8(3), 279-293, doi:10.1029/94GB00993.

This Article is brought to you for free and open access by the Earth Sciences at University of New Hampshire Scholars' Repository. It has been accepted for inclusion in Earth Sciences Scholarship by an authorized administrator of University of New Hampshire Scholars' Repository. For more information, please contact Scholarly.Communication@unh.edu. 


\section{Authors}

David S. Schimel, Rob Braswell, Elisabeth A. Holland, R McKeown, Dennis S. Ojima, Thomas H. Painter, W J. Parton, and Alan R. Townsend 


\title{
Climatic, edaphic, and biotic controls over storage and turnover of carbon in soils
}

\author{
David S. Schimel,' B.H. Braswell, ${ }^{2}$ Elisabeth A. Holland,' Rebecca McKeown, ${ }^{1}$ \\ D.S. Ojima , ${ }^{3}$ Thomas H. Painter, ${ }^{1}$ William J. Parton, ${ }^{3}$ and Alan R. Townsend ${ }^{4}$
}

\begin{abstract}
Soil carbon, a major component of the global carbon inventory, has significant potential for change with changing climate and human land use. We applied the Century ecosystem model to a series of forest and grassland sites distributed globally to examine largescale controls over soil carbon. Key site-specific parameters influencing soil carbon dynamics are soil texture and foliar lignin content; accordingly, we perturbed these variables at each site to establish a range of carbon concentrations and turnover times. We examined the simulated soil carbon stores, turnover times, and $\mathrm{C}: \mathrm{N}$ ratios for correlations with patterns of independent variables. Results showed that soil carbon is related linearly to soil texture, increasing as clay content increases, that soil carbon stores and turnover time are related to mean annual temperature by negative exponential functions, and that heterotrophic respiration originates from recent detritus $(\sim 50 \%)$, microbial turnover $(-30 \%)$, and soil organic matter $(-20 \%)$ with modest variations between forest and grassland ecosystems. The effect of changing temperature on soil organic carbon (SOC) estimated by Century is $d S O C / d T=183 e^{-0.034 T}$. Global extrapolation of this relationship leads to an estimated sensitivity of soil $C$ storage to a temperature of -11.1 $\mathrm{Pg}^{\circ} \mathrm{C}^{-1}$, excluding extreme arid and organic soils. In Century, net primary production (NPP) and soil carbon are closely coupled through the $\mathrm{N}$ cycle, so that as temperatures increase, accelerated $\mathrm{N}$ release first results in fertilization responses, increasing $\mathrm{C}$ inputs. The Century-predicted effect of temperature on carbon storage is modified by as much as $100 \%$ by the $\mathrm{N}$ cycle feedback. Century-estimated soil C sensitivity $\left(-11.1 \mathrm{Pg}^{\circ} \mathrm{C}^{-1}\right)$ is similar to losses predicted with a simple data-based calculation $\left(-14.1 \mathrm{Pg}^{\circ} \mathrm{C}^{-1}\right)$. Inclusion of the $\mathrm{N}$ cycle is important for even firstorder predictions of terrestrial carbon balance. If the NPP-SOC feedback is disrupted by land use or other disturbances, then SOC sensitivity can greatly exceed that estimated in our simulations. Century results further suggest that if climate change results in drying of organic soils (peats), soil carbon loss rates can be high.
\end{abstract}

\section{Introduction}

Soil organic carbon comprises approximately $2 / 3$ of terrestrial carbon storage. It has recently been suggested that soil carbon may play important roles as source [Houghton and Woodwell, 1989; Schimel et al., 1990; Townsend et al., 1992] or sink [Tans et al., 1990; Harrison et al., 1993] of carbon in response to changing climate and atmospheric $\mathrm{CO}_{2}$. Several authors have used indirect evidence to suggest that soils serve [Wofsy et al., 1993] or cannot serve [Schlesinger, 1990] as a sink for carbon on the timescale of decades; some current direct measurements show soils acting as local sources [Oechel et al., 1993]. Interpretation of the role of soils is complicated by the fact that soils contain

\footnotetext{
${ }^{\text {I}}$ National Center for Atmospheric Research, Boulder, Colorado.

${ }^{2}$ Institute for the Study of Earth, Oceans, and Space, University of New Hampshire, Durham.

${ }^{3}$ Natural Resource Ecology Laboratory, Colorado State University, Fort Collins.

${ }^{4}$ Department of Biology, Stanford University, Stanford, Califomia.
}

Copyright 1994 by the American Geophysical Union.

Paper number 94GB00993.

0886-6236/94/94GB-00993\$10.00 fractions of nearly inert (turnover times of thousands of years) and highly active (microbial biomass) carbon, such that estimates of turnover time based on soil $\mathrm{CO}_{2}$ efflux or primary production and total soil carbon are misleading. The modern flux is dominated by small, highly active fractions, while the stores are dominated by the long-lived fractions [Trumbore et al., 1990]. The importance of understanding the partitioning between fractions with different turnover times has been highlighted in recent papers by Trumbore [1993] and Harrison et al. [1993], who used isotope techniques and simple models to estimate the storage of carbon in soils. Despite the advent of isotope techniques, models are clearly required to extrapolate soil dynamics globally. Understanding changes in global soil carbon is further complicated by the difficulty of estimating the current global inventory [Schlesinger, 1977; Post et al., 1985; Eswaran et al., 1993]. A widely used inventory is based on an extrapolation of soil carbon storage based on climatic and vegetation associations [Post et al., 1985; Smith and Shugart, 1993]. Many studies, however, have shown that carbon stores and turnover time are sensitive to a range of factors which are not well-correlated with climate, such as soil texture, and which vary within vegetation types [Burke et al., 1989; Schimel et al., 1985]. Model analyses and better global soil maps [e.g., Webb et al., 1993] can help to identify needed improvements in estimates of the global inventory. 
In this paper we examine the sensitivity of a model of terrestrial organic matter to climate, soil texture, and detrital chemistry. The model (Century) includes coupled submodels for production and decomposition, linked by nutrient cycling ( $\mathbf{N}$ and P). The model explicitly simulates fractions of soil organic carbon that have multiple turnover times and are forced by climate, site soil texture, and prescribed plant detritus chemistry. The model has been extensively validated against measured net primary production (NPP) and soil organic carbon (SOC) storage [Parton et al., 1987; 1994] and against isotopic measures of turnover time [Parton et al., 1994; Townsend, 1993]. The model was integrated to quasi steady state at sites spanning a wide range of temperature and rainfall regimes. We refer to the final state as a "quasi steady state" because interannual variations in climate within the climate record used to initialize the model result in small changes in carbon storage and turnover; results used are averages over the final simulated decades. At each site we analyzed model sensitivity to texture and plant lignin content. We examined texture because many studies [e.g., Burke et al., 1989; Becker-Heidmann and Scharpenseel, 1992; Parton et al., 1994] have shown texture to be a significant control over SOC dynamics, and current global maps of soil texture are very poor. We focused on lignin, a complex polymer produced by vegetation, because it is a significant control over decomposition rates and because lignin concentration is a species-specific characteristic [Parton et al., 1994]. Thus the sensitivity of the model to changing lignin indicates the model's sensitivity to changing vegetation. Many other plant characteristics also influence biogeochemistry, such as allocation patterns and nitrogen content, but lignin concentration exerts the most direct influence and is most readily evaluated [Holland et al., 1992; Parton et al., 1994]. Since plant N uptake and tissue concentrations are computed variables in Century, plant $\mathbf{N}$ cannot be directly perturbed.

\section{Soil Organic Matter Model}

\section{Model Description}

Century is a simulation model of the biogeochemical cycles of terrestrial ecosystems and includes submodels for forests, croplands, savannas, and grasslands. It incorporates representations of net primary productivity (photosynthesis minus respiration), stem respiration, allocation between aboveground and belowground tissue and plant chemistry ( $C: N$ ratio, lignin content). The submodels for the different structural ecosystem types are coupled to a common decomposition and soil organic matter stabilization scheme. The decomposition scheme is described fully by Parton et al. [1987], with important updates documented by Parton et al. [1993]. Several other extant ecosystem models use a scheme similar to or based on Century (G'Day [Comins and McMurtrie, 1993], Linkages [Pastor and Post, 1986], TEM [McGuire et al., 1992]), the relationships among these decomposition schemes are described by Schimel et al. [1991a].

The soil organic carbon scheme is central to this paper; a brief description follows (Figure 1a). Detritus enters the soil or surface litter layer following the death of live plant tissue. The proportions of plant material in readily ("metabolic") and slowly decomposing ("structural") fractions are estimated based on plant nitrogen and lignin contents. Surface and root litter decomposition are simulated separately because of the different microclimatic and nutrient conditions in the soil and surface litter. As detritus decomposes, the remaining unrespired carbon flows into active soil organic matter fractions primarily composed of microbial biomass. A small fraction of the organic matter flows immediately into an intermediate turnover time compartment ("slow SOC"). Turnover of the microbial compartments also contributes to the formation of slow SOC. Decomposition rates of all of these compartments are controlled by climatic parameters and soil texture. Soil texture influences carbon stabilization because the clay particles in soil provide a reactive surface area for the stabilization of SOC in organomineral forms and because clay particles tend to form aggregates which physically protect SOC from decomposition. "Passive" SOC is formed from the turnover of microbial and slow SOC and is composed of organic compounds which are thought to be chemically resistant to further microbial degradation. Turnover of active SOC occurs on annual to decadal timescales, slow SOC on decadal to centennial, and passive on millennial timescales. The equations for the model are presented in detail by Parton et al. [1993], along with site-specific parameters for many of the sites examined in this study.

Nutrients are released during the decomposition of the various detrital and soil organic matter fractions. Each fraction has a range of $\mathrm{C}: \mathrm{N}$ ratios, varying as a function of the amount of inorganic $N$. This has the effect of narrowing the $C: N$ ratios in $N$ rich sites and increasing turnover rates. Data show that forest soils often have wider $\mathrm{C}: \mathrm{N}$ ratios than grasslands. In Century, forest soils are permitted to have wider $C: N$ ratios than grasslands in the slow soil organic matter compartment. During the decomposition of the several soil and detrital components, nutrients are released to an inorganic nutrient pool, associated with the emission of $\mathrm{CO}_{2}$. The amount of $\mathrm{N}$ released is determined by the $\mathrm{C}: \mathrm{N}$ ratio of the compartment and the rate of $\mathrm{C}$ loss as $\mathrm{CO}_{2}$. As part of the microbial growth process ("immobilization"), the detrital compartments may also take up nutrients from the inorganic nutrient compartments. The difference between release (gross mineralization) and uptake of nutrients (immobilization) is known as net mineralization and represents nutrient availability to the growing vegetation. Mineralization of soil nitrogen and phosphorus is the main source of plant-available nutrients, and since most terrestrial ecosystems are nutrient limited (added fertilizer will produce a growth response [Vitousek and Howarth, 1991]), knowledge of global patterns in nutrient availability is crucial to predicting response to land use, and climate and carbon dioxide changes [Schimel et al., 1990; Mc Guire et al., 1992].

\section{Experimental Design}

Century has recently been evaluated as part of a Scientific Commission on the Problems of the Environment (SCOPE) project on primary production and decomposition in temperate forests and grasslands. As part of this study, the model was compared with data on production and soil $\mathrm{C}$ and $\mathrm{N}$ storage at a range of sites worldwide, with generally good agreement in grassland and forest ecosystems. These simulations span significant portions of global biotic and climatic gradients (Figure 1b). Data from these simulations and other validated simulations were used in the analyses presented below. Specifically, the Century model was run to quasi steady state, forced by observed monthly minimum and maximum air temperatures and precipitation [Parton et al., 1993]. The model calculates soil 


\section{CENTURY ORGANIC MATTER FLOW}

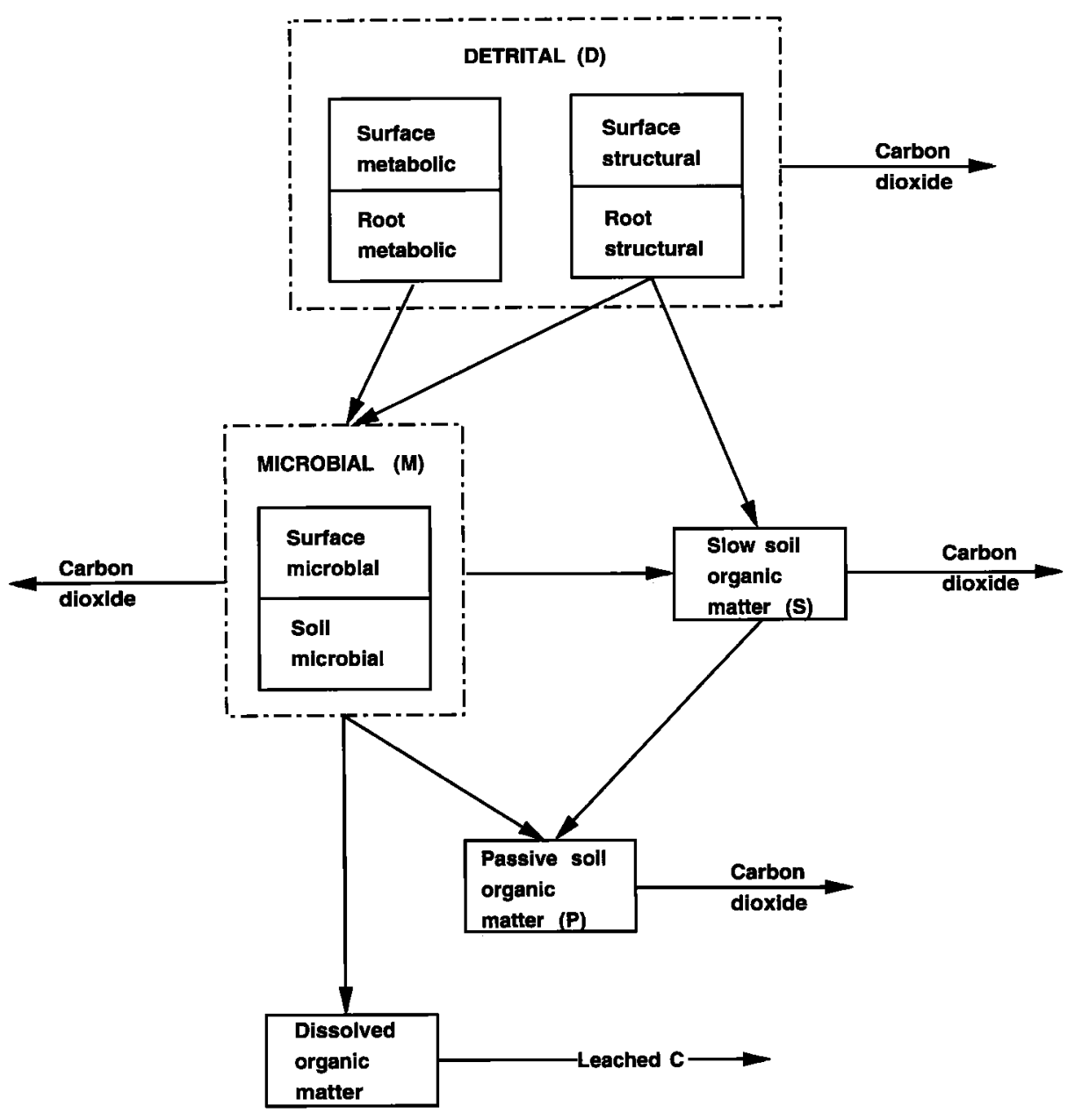

Figure 1a. Compartment structure of the Century model, showing carbon flows and state variables. Controls over rate constants are indicated. The compartments combined for microbial (M), detrital (D), slow (S), and passive (P) are shown.

temperature from air temperature, vegetation biomass, and soil properties. Soil temperature is used in the calculation of decomposition. Turnover times were calculated from compartment size and annual $\mathrm{CO}_{2}$ efflux for each SOC compartment separately and for total SOC. Equations describing the effects of mean annual air temperature (MAT) and texture on total SOC and SOC turnover times (averaged over differences in seasonality of temperatures, effects of precipitation, and vegetation type), were fit using a nonlinear least squares procedure. Simulations with increased temperature but fixed NPP were carried out at selected sites to test the model's sensitivity to the coupling of soil organic matter levels to NPP through the N cycle.

At each site, simulations were performed at eight textures (Table 1) spanning a wide range of clay contents (10-50\% clay). In addition, at eight sites chosen to span the climate range, plant lignin contents were varied between $+50 \%$ and $-50 \%$ of the actual value. We analyzed the effects of changing lignin content on SOC storage, SOC turnover time, slow SOC turnover time, and N mineralization rate. Effects on carbon storage and tumover were expressed as change per percent change in lignin from the observed value (grams per square meter or years per percent change in lignin).

We did not directly simulate soil organic matter formation in peatlands, largely because we are unable to simulate the hydrology which leads to peat accumulation. We did, however, retrieve turnover times of litter compartments from northern sites (similar in composition to peats) to evaluate the potential decomposition rates and turnover times of peats if climate change causes northern peatlands to dry and become aerobic. Turnover times for the separate structural and metabolic litter fractions (Figure 1a) were analyzed separately rather than being aggregated.

\section{Results and Discussion}

\section{Soll Carbon Storage}

Model results show strong (and roughly commensurate) dependency of soil organic carbon storage on mean annual air temperature, lignin, and texture (Figures 2a-2c) over the explored 


\section{SITES USED IN THIS STUDY}

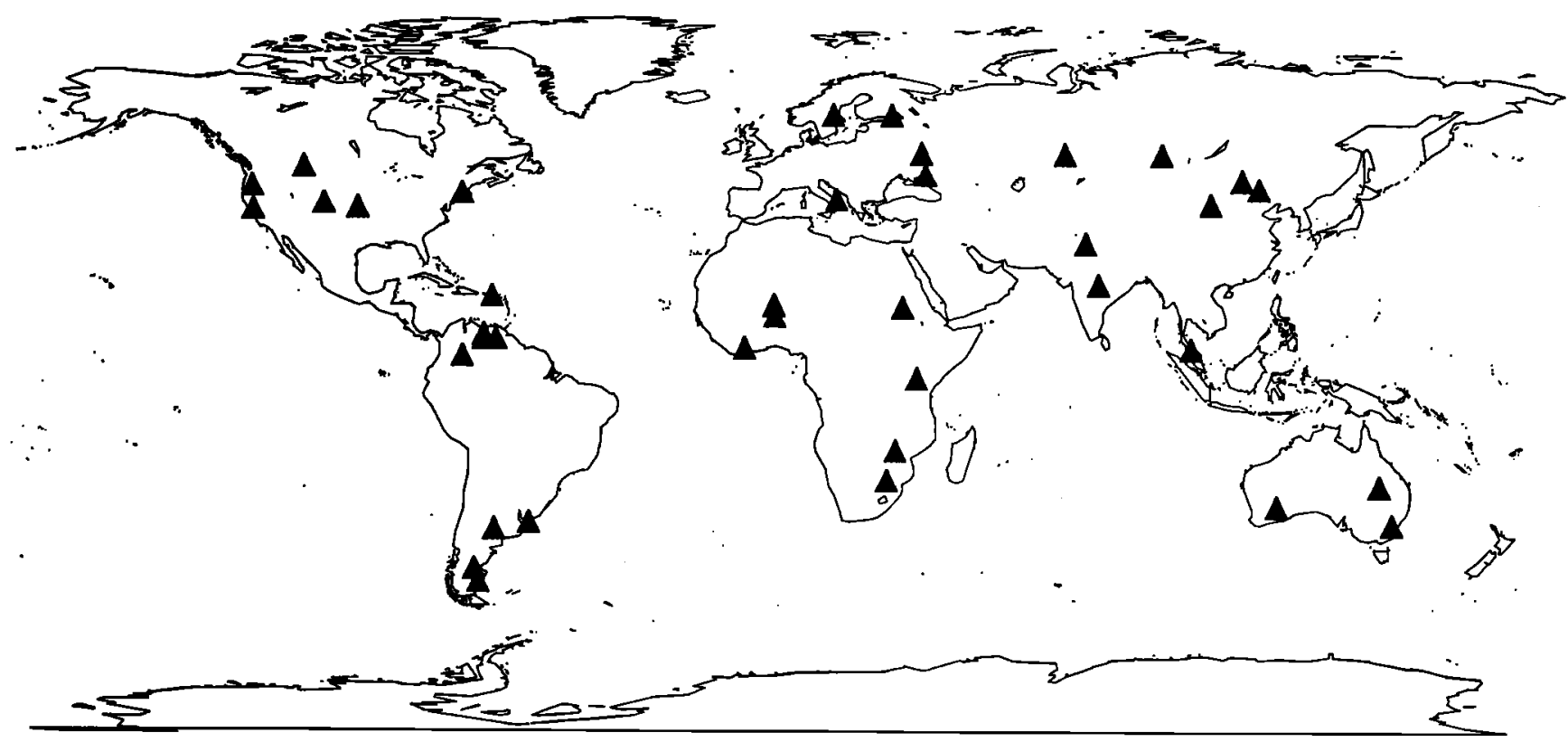

Figure 1b. Map showing sites for simulations.

ranges of these variables. Note that the soil model is driven by monthly soil temperature rather than by MAT. The relationship of SOC storage to temperature can be described by a negative exponential function of temperature (see (1) and Figure 2c) with $\mathbf{R}^{2}>0.75$, averaged over texture (see (1)). The exponent $(-0.034)$ is small enough to be consistent with the near-linear dependencies observed in some regional studies. Model results show $C$ inventories to $20 \mathrm{~cm}$ ranging from $>10 \mathrm{~kg} \mathrm{~m}^{-2}$ in far northern sites to $<3 \mathrm{~kg} \mathrm{~m}^{-2}$ in tropical systems with sandy soils. Much of the vertical scatter apparent in Figure $2 \mathrm{c}$ arises from differences in precipitation between sites of similar temperature.

The predicted effects of texture are significant, with $\mathrm{C}$ inventories varying by $1000-2000 \mathrm{~g} \mathrm{~m}^{-2}$ at a single temperature (Figure 2b). Model results suggest that the effect of texture is slightly larger in cold regions than in warm ones. Texture affected SOC storage in the model primarily by influencing the formation rate of passive $C$; effects on the soil microbial compartment are small [Parton et al., 1994]. Secondary effects of

Table 1. Soil Textures Used in the Texture Sensitivity Analysis

\begin{tabular}{ccc}
\hline Sand & $\begin{array}{c}\text { Silt, } \\
\text { fraction }\end{array}$ & Clay \\
\hline 0.25 & 0.5 & 0.25 \\
0.25 & 0.25 & 0.5 \\
0.25 & 0.65 & 0.1 \\
0.5 & 0.25 & 0.25 \\
0.5 & 0.1 & 0.4 \\
0.5 & 0.4 & 0.1 \\
0.75 & 0.1 & 0.15 \\
0.75 & 0.15 & 0.1 \\
\hline
\end{tabular}

texture occur through its influence on soil hydrologic properties, which affect the water budget and hence both production and decomposition.

Increasing lignin content increased soil carbon storage linearly over the range of lignin values simulated; no relationship was apparent between climatic parameters and sensitivity to lignin. Effects of lignin content ranged globally from 3.3 to $18 \mathrm{~g} \mathrm{~m}^{-2}$ ( $\Delta$ lignin) $)^{-1}$.

The joint global effects of temperature and texture are described by the equation

$$
\text { SOC }=6488 \text { (clay fraction })+5408\left(\mathrm{e}^{-0.034 T}\right)
$$

where $T$ is mean annual temperature, SOC is soil carbon storage, and clay fraction is the fractional content of clay in the soil. This equation was fitted holding lignin constant at the values observed at each site. This equation describes the relationship between large-scale controls (texture and MAT) and SOC, averaging over considerable site-specific differences in seasonality of temperature and moisture, differences between air and soil temperatures, and vegetation characteristics. Both forest and grassland systems follow similar patterns with respect to texture and temperature.

\section{Soil Carbon Turnover Times}

Soil carbon turnover times were strongly influenced by temperature and texture. This relationship is described as follows:

$$
\tau_{\mathrm{soc}}=-16+41 \text { (clay fraction) }+46 e^{-0.03 T}
$$

where $\tau_{\text {soc }}$ is the turnover time (years) for SOC. Turnover times 


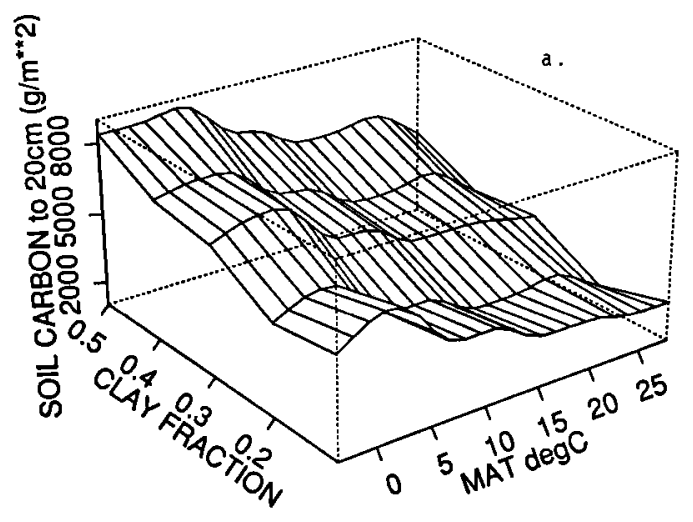

Figure 2. (a) Soil organic carbon (SOC) versus mean annual temperature (MAT) and clay content. (b) SOC versus clay content, averaged over MAT. Lines indicate the range due to MAT. (c) Simulated and observed SOC versus MAT, averaged over temperature. Line indicate the range due to clay content. Data shown are from the U.S. Department of Agriculture compilation described by Buol et al. [1990].

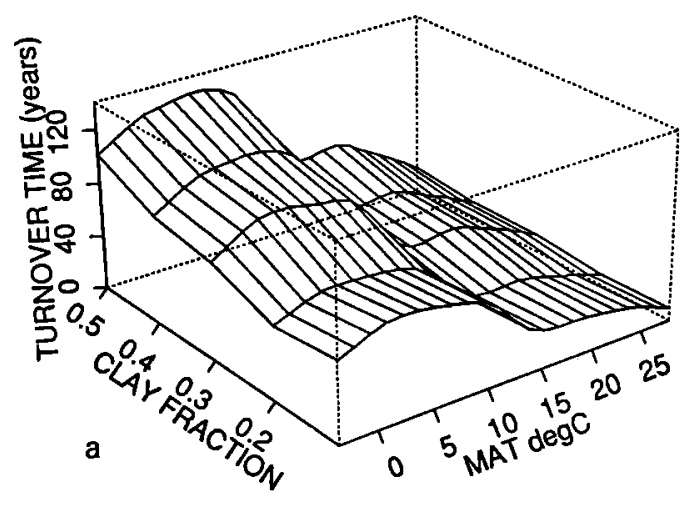

Figure 3. (a) Mean SOC turnover time versus temperature and clay content. (b) Mean SOC turnover time versus clay content, averaged over MAT. Lines indicate the range due to MAT. (c) Mean SOC turnover time versus MAT, averaged over clay content. Lines show the range due to clay content.
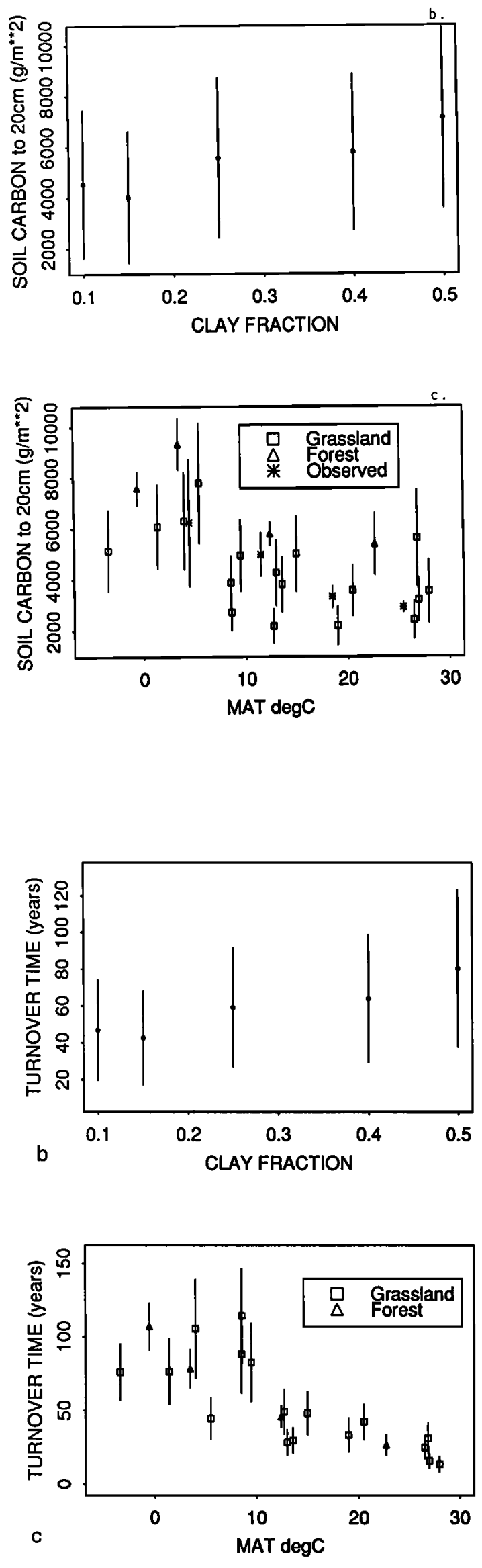
Table 2. Sensitivity of Century Estimates of Soil Organic Carbon (SOC) and Turnover of Slow SOC $\left(\tau_{s}\right)$ to Changing Lignin at Selected Sites

\begin{tabular}{lcc}
\hline Site & $\begin{array}{c}d S O C / d \text { Lignin, } \\
\mathrm{g} \mathrm{m}^{-2}(\Delta \text { Lignin })^{-1}\end{array}$ & $\begin{array}{c}d \tau / d \text { Lignin, } \\
\text { Years }(\Delta \text { Lignin })^{-1}\end{array}$ \\
\hline Colorado & 5.3 & 0.06 \\
Davis, California & 7.3 & 0.06 \\
Australia & 18.5 & 0.15 \\
Kenya & 3.5 & 0.00 \\
Kansas & 3.3 & 0.01 \\
Mali & 4.0 & 0.00 \\
Thailand & 4.0 & 0.00 \\
Siberia & 10.6 & 0.07 \\
\hline
\end{tabular}

for SOC, computed as the weighted average of the several pools, ranged from $>100$ years in cold, clay soils to $<20$ years in sandy tropical soils (Figures 3a-3c). Texture effects were clearly larger in cold soils, with differences of $>40$ years between clay fractions of 0.1 and 0.5 (Figure $3 \mathrm{~b}$ ). Tropical soils showed turnover time ranges due to texture of $<20$ years. Increasing lignin increased turnover time for SOC, primarily through changes in slow SOC turnover, by 0.01 to 0.1 years ( $\Delta$ lignin) $)^{-1}$, a significant effect because changes in lignin of $100-300 \%$ between vegetation types are possible (Table 2).

It is important to note that the turnover time of total SOC is misleading, as it is the average over compartments with turnover times ranging in a single soil from -1 year to thousands of years.
In a soil with an average turnover time of 40 years, $-30 \%$ of SOC will be in a compartment with turnover time of $>1000$ years. The average turnover time is thus merely an indicator of the impact of climate on SOC turnover and ignores the dynamics of multiple compartments with different turnover times. As noted before, texture influences average turnover time by increasing the proportion of SOC stored in the passive fraction, thus adding more long-turnover time SOC into the average. Changing lignin primarily affects the turnover of slow SOC [Parton et al., 1994]. The compartment-specific turnover times are discussed below.

\section{Partitloning of SOC and Turnover Times}

Turnover times for the separate compartments in Century are influenced by temperature and were fitted by negative exponential curves, reflecting the underlying temperature parameterization, in which decomposition rates increase rapidly with increasing temperature. For ease of analysis we lumped the eight detrital and soil organic matter compartments into the four following (see also Figure 1): (1) microbial (M), surface microbes plus soil active organic matter; (2) detrital (D), surface structural, plus surface metabolic, plus root structural, plus root metabolic organic matter; (3) slow; and (4) passive.

To a first approximation, global variations in the turnover times of the above four compartments can be explained by an exponential dependence of turnover on temperature. This is a direct reflection of the underlying parameterization of microbial activity versus temperature, although precipitation and seasonality of temperature also influence microbial activity. The microbial compartments show a slight dependency on texture,
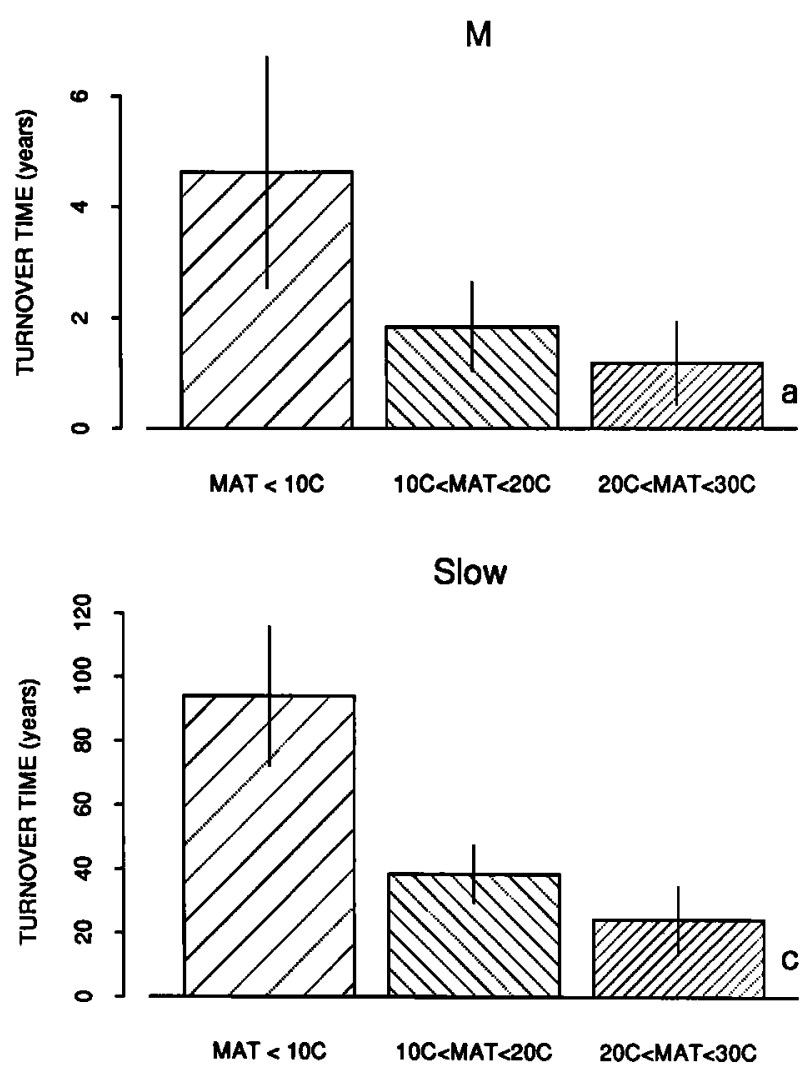

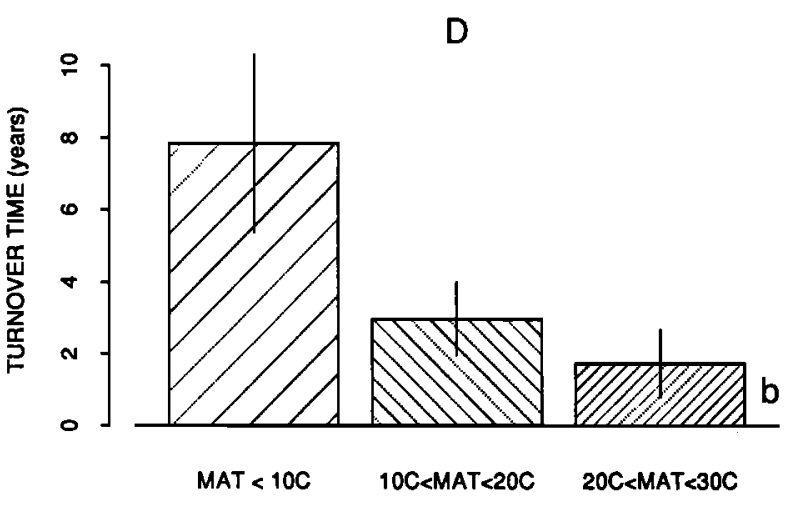

Passive

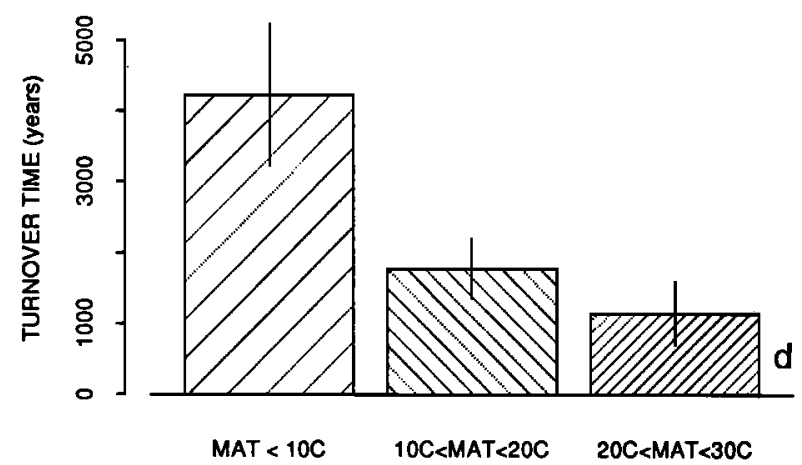

Figure 4. Turnover times of Century SOC fractions versus MAT for (a) microbial SOC, (b) detrital SOC, (c) slow SOC, and (d) passive SOC. MAT is shown as three zones, MAT $<10^{\circ} ; 10^{\circ}<\mathrm{MAT}<20^{\circ}$; and $20^{\circ}<\mathrm{MAT}<30^{\circ}$. 
reflecting a parameterization in Century designed to capture effects of texture on microbial turnover [Schimel, 1986; Gregorich et al., 1991; Juma, 1993]. Figures 4a-4d show turnover times for $M, D$, slow, and passive organic matter averaged over textures and further averaged into $10^{\circ} \mathrm{C}$ MAT bands ( \pm range over sites and textures), illustrating the exponential nature of the relationship. Equations describing the relationships between the compartment-specific turnovers, temperature, and texture are:

$$
\begin{aligned}
& \tau_{\mathrm{m}}=-5.3+5.2 \text { (clay fraction) }+8.8 e^{-0.02 T} \\
& \tau_{d}=-0.1+0.6 \text { (clay fraction) }+7.3 e^{-0.04 T} \\
& \tau_{s}=-67+9.1 \text { (clay fraction) }+159 e^{-0.02 T} \\
& \tau_{p}=-3300+370 \text { (clay fraction) }+7400 e^{-0.02 T}
\end{aligned}
$$

where $\tau_{m} \tau_{d} \tau_{s,}$ and $\tau_{p}$ are the turnover times for the compartments defined above and clay fraction is the fractional content of clay in the soil. In Century, lignin is routed to the slow SOC compartment, and changing lignin significantly affected slow turnover at some sites (Table 2). No relationship between Century sensitivity to lignin and climate was apparent.

\section{Partitioning of Respiration and C:N Ratios}

The carbon in heterotrophic respiration originates from three primary compartments in Century and is distributed with remarkable constancy among those compartments across wide ranges of MAT and percent clay but within vegetation types (Figure 5a). In virtually all simulations, about half of heterotrophic respiration came from decomposition of surface and root detritus (D), slightly higher in grasslands, and slightly lower in forests (Figure 5b). The difference between vegetation types is due to the higher turnover rates of the generally lower ratio of lignin to nitrogen detritus in grasslands. An additional $-30 \%$ of heterotrophic respiration came from turnover of the surface and soil microbial biomass. The remaining $20 \%$ of heterotrophic respiration is derived from the slow SOC compartment, which has a turnover time varying globally from -10 (tropics) to $>100$ (boreal) years (Figure $4 \mathrm{c}$ ). Note that heterotrophic respiration is $50-70 \%$ of total soil respiration, the remainder being autotrophic or root respiration [e.g., Raich and Schlesinger, 1992].

C:N ratios were generally higher in forests than in grasslands, most notably in detrital and slow SOC compartments (Figure $5 \mathrm{c}$ ). There were significant variations in detrital $C: N$ ratio within grasslands. While Century permits the $\mathrm{C}: \mathrm{N}$ ratios of the soil compartments to vary in response to mineral $\mathbf{N}$ levels, our simulations reveal little variability in $\mathrm{C}: \mathrm{N}$ ratios of soil (as opposed to detrital) compartments (Figure 5c). This is because in the natural ecosystems simulated in this series of model experiments, nearly balanced processes of uptake and release occurred. The variable $C: N$ ratio feature of the model is important in simulating decomposition in agroecosystems, in which wide variations in soil mineral $\mathbf{N}$ occur during fallow cycles and in response to fertilization.

The partitioning of $\mathbf{N}$ into organic matter fractions, which in Century parallel the carbon fractions, significantly influences the response of ecosystems to disturbance or climate change. Only the slow SOC compartment offers a significant reserve of
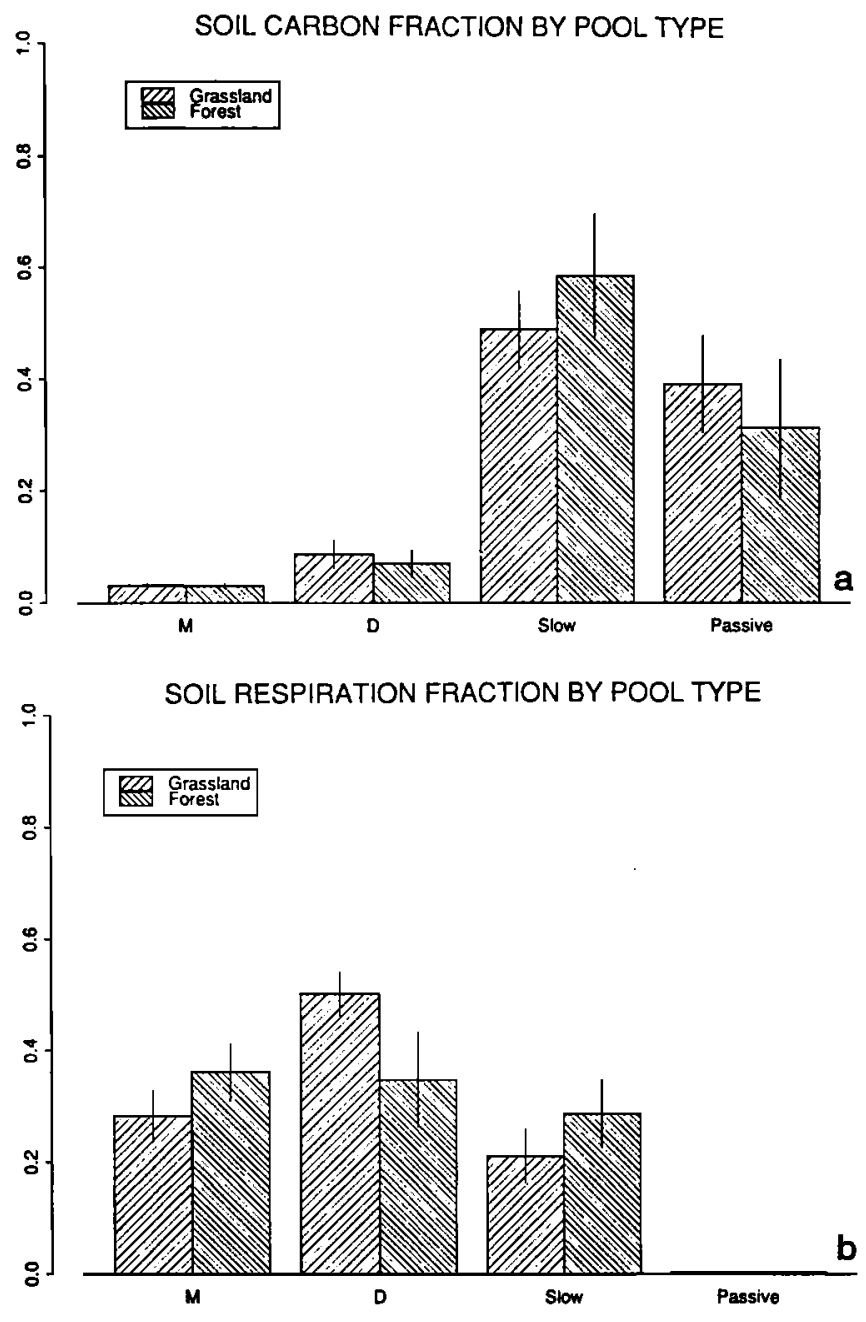

C/N RATIO BY POOL TYPE

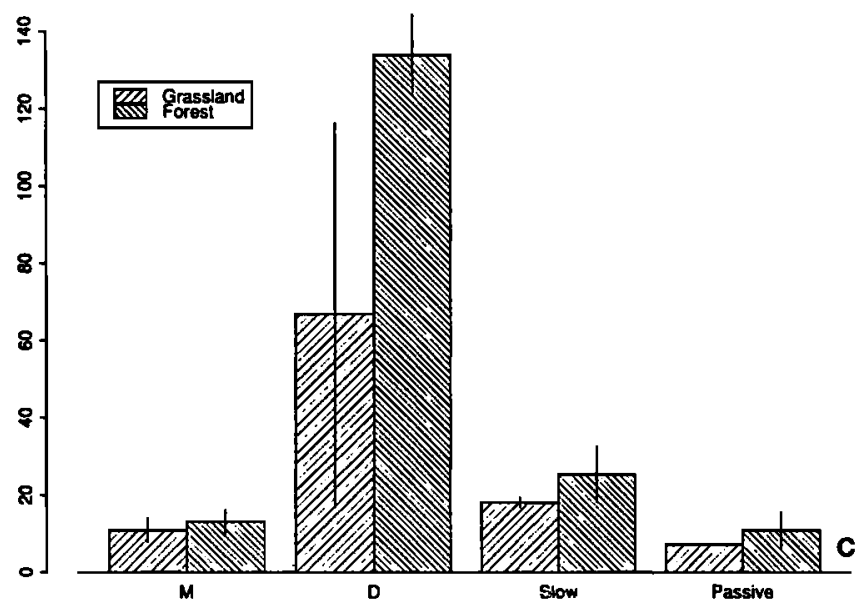

Figure 5. (a) Fraction of forest and grassland SOC in M, D, slow, and passive SOC, averaged over all simulations. Vertical lines show standard deviations. (b) Fraction of forest and grassland heterotrophic respiration from $M, D$, slow, and passive fractions. Vertical lines show standard deviations. Note that while slow and passive fractions dominate the inventory, the active fractions dominate the respiration flux. (c) C:N ratios for $M, D$, slow, and passive fractions in forests and grasslands. 
available $\mathrm{N}$, as the microbial compartments are a very small fraction of SOM, the passive can only contribute slowly, and the detrital compartments actually serve as an $\mathrm{N}$ sink because of their wide C:N ratios. Thus the slow compartment serves as an $\mathbf{N}$ reserve, contributing $\mathbf{N}$ fertility when it declines, as in the early years of cultivation following land conversion [Schimel et al., 1985]. If the slow compartment declines in response to temperature change, then the $\mathrm{N}$ released can contribute to increased plant productivity and decreased net ecosystem $\mathbf{C}$ losses associated with increased decomposition [Schimel et al., 1990; Shaver et al., 1992]

\section{Soll $\mathrm{C}$ and the Global C Cycle}

There has been considerable discussion of the role of soils in the global carbon cycle. Tans et al. [1990] suggested that carbon storage resulting from a large sink for atmospheric $\mathrm{CO}_{2}$ (deduced from atmospheric concentration gradients) might be stored in soil or litter, as it had not been identified in inventories of living forest components. Schlesinger [1990] responded to this suggestion by arguing that soils could not accrete carbon at the rates implied by the Tans et al. [1990] scenario based on an analysis of rates of carbon accumulation in undisturbed soils from chronosequences [Schlesinger, 1990]. Others have suggested that future warming should release $\mathbf{C}$ from soils because the temperature response of heterotrophic respiration (carbon loss) is greater than that of photosynthesis (carbon gain) [Houghton and Woodwell, 1989; Schimel et al., 1991a,b; Townsend et al., 1992].

Our study speaks to both of these issues. First, in our model experiments, $50 \%$ to $70 \%$ of SOC to $20 \mathrm{~cm}$ resides in compartments with turnover times of $\leq 100$ years. These compartments can respond to a changing balance of inputs and outputs on timescales commensurate with the anthropogenic $\mathrm{CO}_{2}$ perturbation. Century predicts that in 10 years, $50 \%$ of tropical, $25 \%$ of midlatitude, and $20 \%$ of high-latitude mineral soil SOC will turn over. The accretion rates for old landscapes presented by Schlesinger [1990] may reflect the time required to accumulate profile-integrated passive SOC rather than the time required for detrital, microbial, and slow SOC to adjust to changing inputs or losses (W.H. Schlesinger, personal communication, 1993). Schlesinger's [1990] study assumes that young landscapes and disturbed systems, which represent nonsteady state conditions and have high rates of carbon accumulation, do not cover sufficient area to account for the Tans et al. [1990] sink. Young or disturbed soils may have dominated changes in carbon storage in recent decades [Harden et al., 1992; Parton et al., 1994]. Century simulations and a host of field studies demonstrate that increases in soil carbon can occur over decades [Parton et al., 1994; Jenkinson and Raynor, 1977; Paustian et al., 1990; Nadlehoffer et al., 1987]. We suggest that if $\mathrm{CO}_{2}$ or fertilizer and pollutant $\mathrm{N}$ increase global NPP over the coming decades, soil carbon increases can occur on a commensurate timescale.

Second, the derivative of steady state $S O C$ to $20 \mathrm{~cm}$ depth with respect to temperature, estimated from our ensemble of simulations, ranges from 78 to $200 \mathrm{~g} \mathrm{~m}^{-2}{ }^{\circ} \mathrm{C}^{-1}$ as a function of MAT $\left(d S O C / d T=183 e^{-0.034 T}\right)$. This suggests that effects on SOC of a $1-4^{\circ} \mathrm{C}$ temperature change are of the order of $10 \%$ of SOC to $20 \mathrm{~cm}$ depth or $-3-5 \%$ of the total $\mathrm{C}$ to $1 \mathrm{~m}$ depth. Additional warming would have progressively less effect on $\mathrm{C}$ storage. The estimated effect of warming is sensitive to the feedback between primary production and decomposition via the $\mathbf{N}$ cycle. We compared simulations of warming effects at eastern Colorado sites, with NPP held constant at the control level, to simulations in which NPP was computed interactively as a function of climate and $\mathbf{N}$ availability. SOC losses were nearly doubled when NPP was fixed, compared with the normal coupled CENTURY simulations ( $d S O C / d T=-193$ versus $-102 \mathrm{~g} \mathrm{~m}^{-2}$ ), reflecting an increase in plant production of $22 \%$ in the coupled simulation. The increase in plant production arises from the release of mineral $\mathbf{N}$ from the respired soil organic matter (a $30 \%$ increase in $\mathbf{N}$ availability).

We used soil area and density information from Eswaran et al. [1993] and global mean annual temperature (MAT) data from Legates and Willmott [1990] to globally extrapolate the effect of temperature on soil carbon storage. We excluded from this calculation aridisols (desert soils) because these soils may have insufficient SOC to sustain projected losses $\left(-100 \mathrm{~g}^{\circ} \mathrm{C}^{-1}\right)$. We also excluded histosols (organic or peat soils) because Century does not simulate peat-forming conditions well (but see Implications for Peat section below). We estimate the effect of warming (Table 3) on steady state SOC storage as $-3.1 \mathrm{Pg}^{\circ} \mathrm{C}^{-1}$ in the tropics and $\mathbf{- 8 . 0}$ in the mid- to high latitudes for a global total of $-11.1 \mathrm{Pg}^{\circ} \mathrm{C}^{-1}$ to $20 \mathrm{~cm}$ depth. Most of these losses will come from slow ( $-55 \%$ of SOC) and passive SOC ( $-35 \%$ of SOC), in proportion to their abundance in the soil, and so $-55 \%$ of the tropical response will occur in tens of years, while the highlatitude response requires $>100$ years (based on the turnover times of slow and passive SOC). The full steady state response will require thousands of years because of the millenial year turnover times of the passive SOC.

How does this result compare with other calculations? Jenkinson et al. [1991] estimated a global loss of $-34 \mathrm{Pg}^{\circ} \mathrm{C}^{-1}$

Table 3. Comparison of Modeled and Observed Change in Temperature on Soil Organic Carbon by Zone

\begin{tabular}{lcccc}
\hline Model & $\begin{array}{c}\text { Tropical, } \\
\mathrm{Pg}^{\circ} \mathrm{C}^{-1}\end{array}$ & $\begin{array}{c}\text { Extra- } \\
\text { tropical, } \\
\mathrm{Pg}^{\circ} \mathrm{C}^{-1}\end{array}$ & $\begin{array}{c}\text { Global, } \\
\mathrm{Pg}^{\circ} \mathrm{C}^{-1}\end{array}$ & Depth \\
\hline $\begin{array}{l}\text { Buol et al. } \\
{[1990]}\end{array}$ & -2.4 & -11.7 & -14.1 & $20 \mathrm{~cm}$ \\
$\begin{array}{l}\text { Century } \\
\text { Melillo et } \\
\text { al. }[1994]\end{array}$ & -3.1 & -8.0 & -11.1 & $20 \mathrm{~cm}$ \\
$\begin{array}{l}\text { Townsend } \\
\text { et al. } \\
{[1992]}\end{array}$ & -15 & $\mathrm{NA}$ & -18.8 & $20 \mathrm{~cm}$ \\
$\begin{array}{l}\text { Jenkinson } \\
\text { et al. }\end{array}$ & NA & NA & -33.8 & $1 \mathrm{~m}$ \\
$\begin{array}{l}\text { [1991] } \\
\begin{array}{l}\text { Esser } \\
{[1990]}\end{array}\end{array}$ & NA & NA & -32.5 & $1 \mathrm{~m}$ \\
$\begin{array}{l}\text { Friedlingst } \\
\text { ein } \\
{[1992]}\end{array}$ & NA & NA & -21.0 & $1 \mathrm{~m}$ \\
$\begin{array}{l}\text { Potter et } \\
\text { al. }[1993]\end{array}$ & NA & NA & -26.6 & $30 \mathrm{~cm}$ \\
\hline
\end{tabular}

NA indicates not applicable. 
(Table 3). A loss to $20 \mathrm{~cm}$ depth of $-18.8 \mathrm{Pg}$ and a loss of -42.7 $\mathrm{Pg}^{\circ} \mathrm{C}^{-1}$ to $100 \mathrm{~cm}$ has been estimated using the terrestrial ecosystem model (TEM) (J.M. Melillo, personal communication, 1993). Esser [1990] calculated an effect of $-32.5 \mathrm{Pg}^{\circ} \mathrm{C}^{-1}$. Townsend et al. [1992] estimated losses of $-23.2 \mathrm{Pg}^{\circ} \mathrm{C}^{-1}$ globally, with $-15 \mathrm{Pg}^{\circ} \mathrm{C}^{-1}$ in the tropics, $-11 \mathrm{Pg}^{\circ} \mathrm{C}^{-1}$ in the temperate zone (Table 3), and an estimated uptake of $2.8 \mathrm{Pg}^{\circ} \mathrm{C}^{-1}$ in the boreal and tundra zones. Friedlingstein's [1992] model has a sensitivity of $-21 \mathrm{Pg}^{\circ} \mathrm{C}^{-1}$ (P. Friedlingstein, personal communication, 1993). Potter et al. [1993] calculated a sensitivity of $-26 \mathrm{Pg}^{\circ} \mathrm{C}^{-1}$ to $30 \mathrm{~cm}$ $(-21.5 \mathrm{Pg}$ to $20 \mathrm{~cm})$ using Carnegie-Ames-Stanford Approach (CASA). This result is of particular interest, as the soil decomposition submodel of CASA closely follows Century and uses very similar parameterizations. However, in CASA, NPP is calculated from intercepted photosynthetically active radiation (IPAR) and a growth efficiency $\varepsilon$, which is modified by climate. The IPAR estimates are derived from the satellite normalized difference vegetation index product [Sellers et al., 1992]. In the $1^{\circ} \mathrm{C}$ sensitivity experiment, increased temperature decreases NPP very slightly (from 48 to $47.5 \mathrm{Pg}$ ), compared with Century, in which a $1^{\circ} \mathrm{C}$ increase causes an average $20 \%$ increase in NPP through the $\mathrm{N}$ cycle. The intercomparison shows broad convergence of estimates, although models which assume uniform turnover times to $1 \mathrm{~m}$ depth or which omit the $\mathbf{N}$ cycle feedback tend to be more sensitive to warming than Century.

We also compared our estimated sensitivity with a simple empirical model based on data assembled by Buol et al. [1990] (Figure 2c and Table 3). Buol et al. [1990] used data from a U.S. Department of Agriculture global soils data base and examined soil carbon as a function of mean annual temperature, with temperatures aggregated based on the temperature classes used in the U.S. Soil Taxonomy. We rescaled Buol et al.'s data by 0.83 to take into account the difference in $C$ between 20 and $30 \mathrm{~cm}$ depths based on examination of a number of soil profiles. We fitted an exponential function to SOC versus $T$ and took the derivative of that relationship as an estimate of steady state sensitivity. The mean estimated sensitivity for the extratropical regions was $192 \mathrm{~g} \mathrm{~m}^{-2}{ }^{\circ} \mathrm{C}^{-1}$, leading to a loss of $11.7 \mathrm{Pg}^{\circ} \mathrm{C}^{-1}$ from the mid- to high latitudes, well within the uncertainty of the Century estimate. Buol et al.'s [1990] data suggest a loss of 59.5 $\mathrm{g} \mathrm{m}^{-2}{ }^{\circ} \mathrm{C}^{-1}$ or $2.4 \mathrm{Pg}^{\circ} \mathrm{C}^{-1}$ from the tropics as a whole, again, in close agreement with Century. The correspondence of the model estimates with Buol et al.'s [1990] data and the extensive sitespecific validation of Century [Parton et al., 1993, 1994] suggest reasonable credibility for simulated SOC storage and turnover times and for Century's ability to roughly simulate the magnitude and timescale of global soil carbon changes.

At any given site the effect for temperature changes of $<4^{\circ} \mathrm{C}$ is small $(-10 \%$ of $\mathrm{SOC})$ compared to the effects of disturbance, which can be of the order of $30-40 \%$ of SOC to $20 \mathrm{~cm}$ [Davidson and Ackerman, 1993]. Effects of temperature on SOC below 20 $\mathrm{cm}$ will be smaller, since the turnover time of SOC increases with depth [Scharpenseel and Becker-Heidmann, 1992], an effect not considered in most of the models reviewed in this paper [Townsend et al., 1992; Esser, 1990]. However, both model experiments and copious field experience indicate that when ecosystems are disturbed, significant losses of soil carbon and nutrients occur [Parton et al., 1994]. If rapid climate change causes ecosystems, or some ecosystems, to "fall apart," the simple derivative at steady state suggested by our model experiments may be irrelevant.

\section{Global Turnover and Decay Times}

We fitted Century-simulated mean turnover times (from data shown in Figure 3) to MAT and soil texture (clay fraction) using the nonlinear fit described above. Mean turnover time is computed from SOC divided by respiration and is the average of compartment turnover times that range from -1 year to $>1000$ years. The mean turnover time is useful in that it integrates the climatic and vegetation type effects (which affect the compartment turnover times) with soil texture (which affects the partitioning between fractions with different tumover times). We extrapolated potential mean turnover globally by overlaying the Legates and Willmott [1990] mean annual temperature field on a soil texture map derived from the Food and Agriculture Organization global soil map [Zobler, 1986]. Note that while turnover times were extrapolated spatially, the equations were not extrapolated outside the temperature range used in developing the equation (the extreme high latitudes are shown as "longer than $\mathbf{7 0}$ years"). In this analysis, large inland water bodies and extensive peatlands were excluded. Deserts, where SOC accumulation and turnover are significantly limited by precipitation, were not excluded, but our extrapolated results in harsh desert environments should not be given credence without further testing. These regions contribute little to global organic $\mathbf{C}$ storage or flux [Melillo et al., 1993]. Plate 1a shows SOC turnover mapped with the entire land surface set to a common texture ( $20 \%$ clay), thereby isolating the effects of temperature. Note the strong zonal pattern of turnover, with estimated turnovers in excess of 70 years at high latitudes and $<20$ years in the tropics. The addition of texture changes the geography of turnover rates considerably, with dramatic effects in the tropics. Since many of the world's fine-textured soils are in the tropics, the influence of texture has the effect of increasing the fraction of passive SOC in the tropics relative to the expectation based solely on temperature, thus increasing the average turnover time. The highly weathered clays found in some tropical soils may stabilize less SOC than clays typical of temperate regions, modifying this response. However, the effects of clay mineralogy are not in the current version of Century.

In order to better understand the effects of model structure and zonal turnover rates on SOC dynamics, we computed the decay function of the system of equations for detrital, microbial, slow, and passive SOC, with inputs set to zero. We computed this two ways. First, we computed $\operatorname{SOC}$ at time $t(\operatorname{SOC}(t))$ as the sum of the separate pools $(M, D, S$, and $P)$ at each time step from

$$
\operatorname{SOC}(t)=\Sigma w_{i} \operatorname{SOC}_{i}(0) e^{-k_{t}}
$$

where $w_{l}$ is the fraction of $\operatorname{SOC}(0)$ in compartment $i$ (i.e., M, D, slow, passive), from Figure $5 \mathrm{a}$, with decay constant $k_{l}$, estimated zonally as a function of temperature and texture using (3)-(6). Then, we computed

$$
\operatorname{SOC}(t)=\operatorname{SOC}(0) e^{-\bar{k} t}
$$

where $\bar{k}=\Sigma\left(w_{i} k_{i}\right)$, the mean decay constant for the four pools, applies to an average SOC pool instead of to the individual pools (equivalent to a one-pool model). The $k$ 's in (7) are estimated by zonally averaging the results shown in Plate $1 \mathrm{~b}$.

Figure 6 shows the results. Note, first, the significant zonal differentiation in decay times, with initially higher rates in the 
(a)

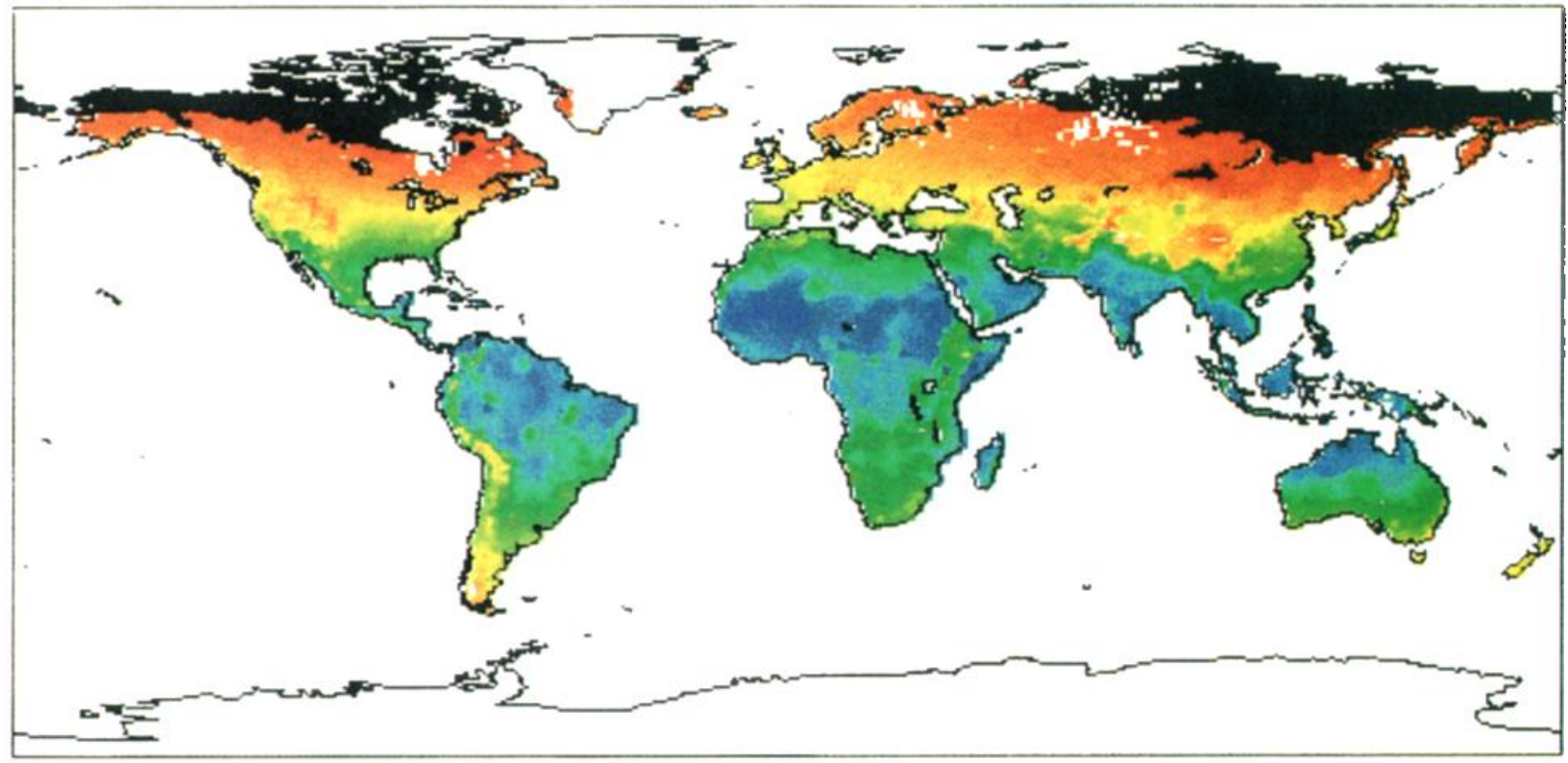

(b)
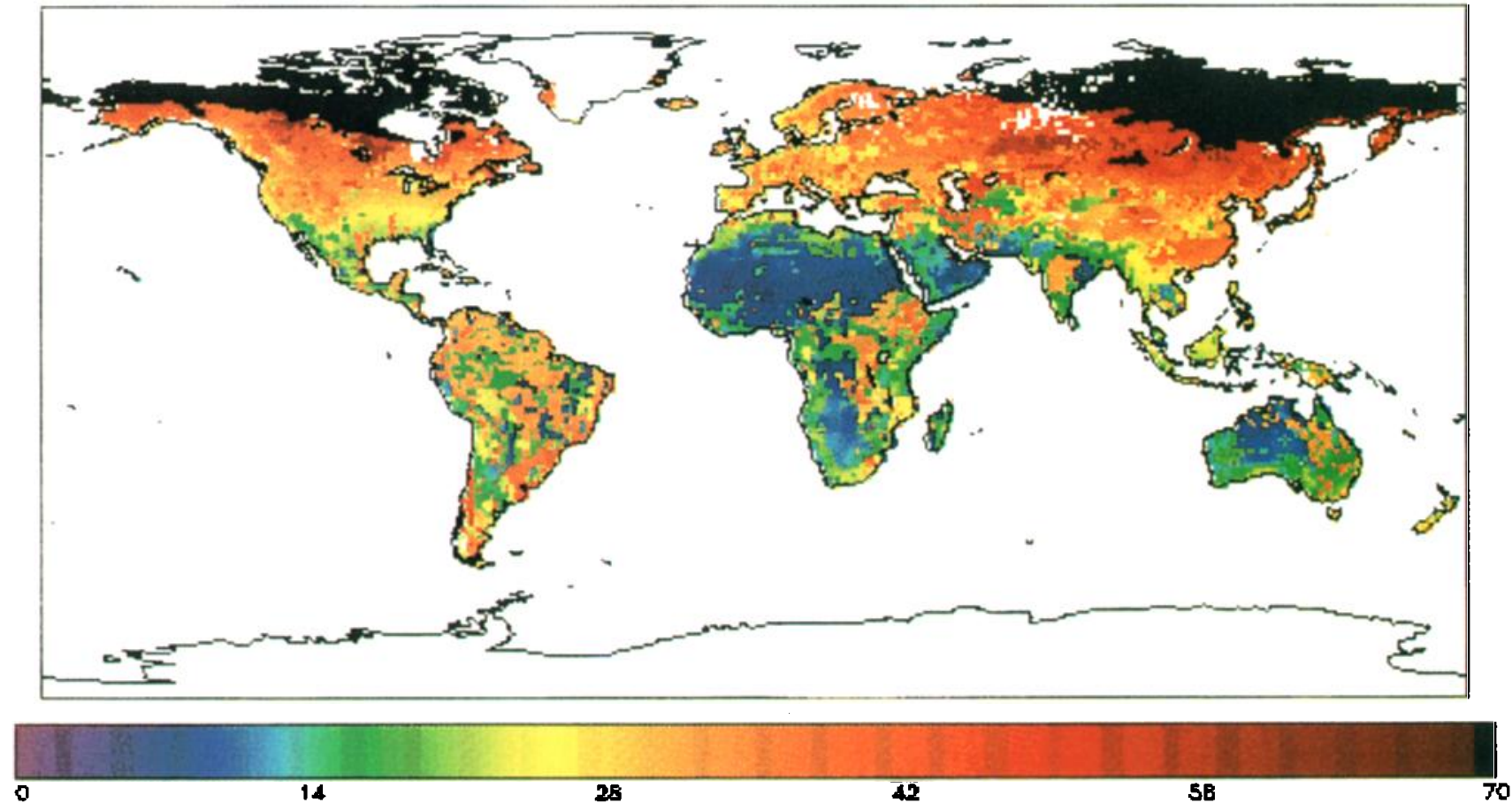

Plate 1. (a) Potential mean soil carbon turnover times extrapolated globally based on temperature, with texture set constant at $20 \%$ clay. (b) Potential mean soil carbon turnover rates extrapolated based on temperature and texture. Results were extrapolated using equation (2). Areas shown in black in both plates $1 \mathrm{a}$ and $1 \mathrm{~b}$ are outside the temperature range used in developing the equation. Note the significant reorganization of the turnover geography which occurs as a result of the bias toward fine-textured (high clay) soils in the tropics.

tropics (MAT $>20^{\circ} \mathrm{C}$ ). Note also that the timescale for decay in the four-pool cases is more than thousands of years due to the existence of the passive pool. Components of ecosystem response are controlled by the dynamics of soil recalcitrant fractions, untroducing considerable lags, as has also been shown in transient calculations with Century under perturbed conditions [Schimel et al., 1990].
Second, note the difference between the response of the oneand four-pool models. The former model has much faster dynamics than the latter, with overlapping trajectories for $<25$ model years. Between-model differences are much larger than zonal effects. While the one-pool model (similar to Townsend et al.'s [1992] model) shows zonal differentiation, its dynamics are almost certainly too fast. It seems unlikely to us that a one-pool 
model of soil organic matter will yield realistic transient responses if any significant departure from steady state occurs.

\section{Implications for Isotopes}

The zonal distribution of the $\delta^{13} \mathrm{C}$ of atmospheric $\mathrm{CO}_{2}$ is an important tracer in carbon cycle calculations [Quay et al., 1992; Tans et al., 1993; Harrison et al., 1993]. Many calculations assume that $\mathrm{CO}_{2}$ returned to the atmosphere via respiration has the same isotopic signature as recently fixed photosynthate; that is, it should have the signature of the photosynthetic pathway (roughly -14 or $-27 \%$ relative to Pee Dee belemnite (PDB)) modified over decades by the slow change in atmospheric $\delta^{13} \mathrm{C}$ due to human perturbation of the $C$ cycle (1.5\%o since the beginning of the industrial revolution [Stuiver et al. 1984]). Tans et al. [1993] have argued that because soil respiration, an important component of terrestrial respiration, comes from a compartment with a long turnover time, there will be a lag in respired ${ }^{13} \mathrm{CO}_{2}$ relative to the changing atmosphere. Because of this, even if photosynthesis and respiration are balanced overall, there will be a positive flux of ${ }^{13} \mathrm{C}$ to the atmosphere. This will affect calculations, such as those presented by Quay et al. [1992]. Here we present a brief analysis of the lag effect due to soil respiration.

First, about $30-50 \%$ of soil respiration comes from root respiration, and this $\mathrm{CO}_{2}$ should bear the same isotopic signature as photosynthate [Raich and Schlesinger, 1992; Peterjohn et al., 1993]. Our model predicts that of the remaining $-50-70 \%$ of respiration, $25 \%$ originates from detrital turnover, $15 \%$ from microbial turnover, and $10 \%$ from slow SOC turnover. Detritus with global turnover times (except in peatlands) of $<10$ years should have an isotopic signature lagged by, at most, $0.1 \%$ and modified by photosynthetic fractionation relative to the atmosphere, given the rate of change of $\delta^{13} \mathrm{CO}_{2}(-0.02 \%$ yr [Tans et al., 1993]). The microbial biomass is largely derived from recent detritus and so should have a similar isotopic signature. Only the $<20 \%$ of soil respiration derived from slow SOC should be significantly lagged relative to the atmosphere. The turnover time of slow SOC, again excepting peats, varies from $\sim 15$ years in the tropics to -90 years in the high latitudes (compared with Harrison et al.'s [1993] suggestion of a global mean turnover time of 25 years for slow SOC). This suggests that a lag effect could be important, especially in high latitudes. A full analysis of the effect of soils on atmospheric $\delta^{13} \mathrm{C}$ is given by $R$. Ciais et al. (Partitioning of ocean and land uptake of $\mathrm{CO}_{2}$ as inferred by $8^{13} \mathrm{C}$ measurements from the NOAA/CMDL global air sampling network, submitted to Global Biogeochemical Cycles, 1994).

\section{Implications for Peat}

A significant fraction of global SOC is stored as peat. Peat is composed of partially decomposed plant detritus, in which further decomposition is arrested or greatly slowed by a combination of anaerobic conditions, low temperatures, low $\mathrm{pH}$, and nutrient impoverishment. Century simulates decomposition

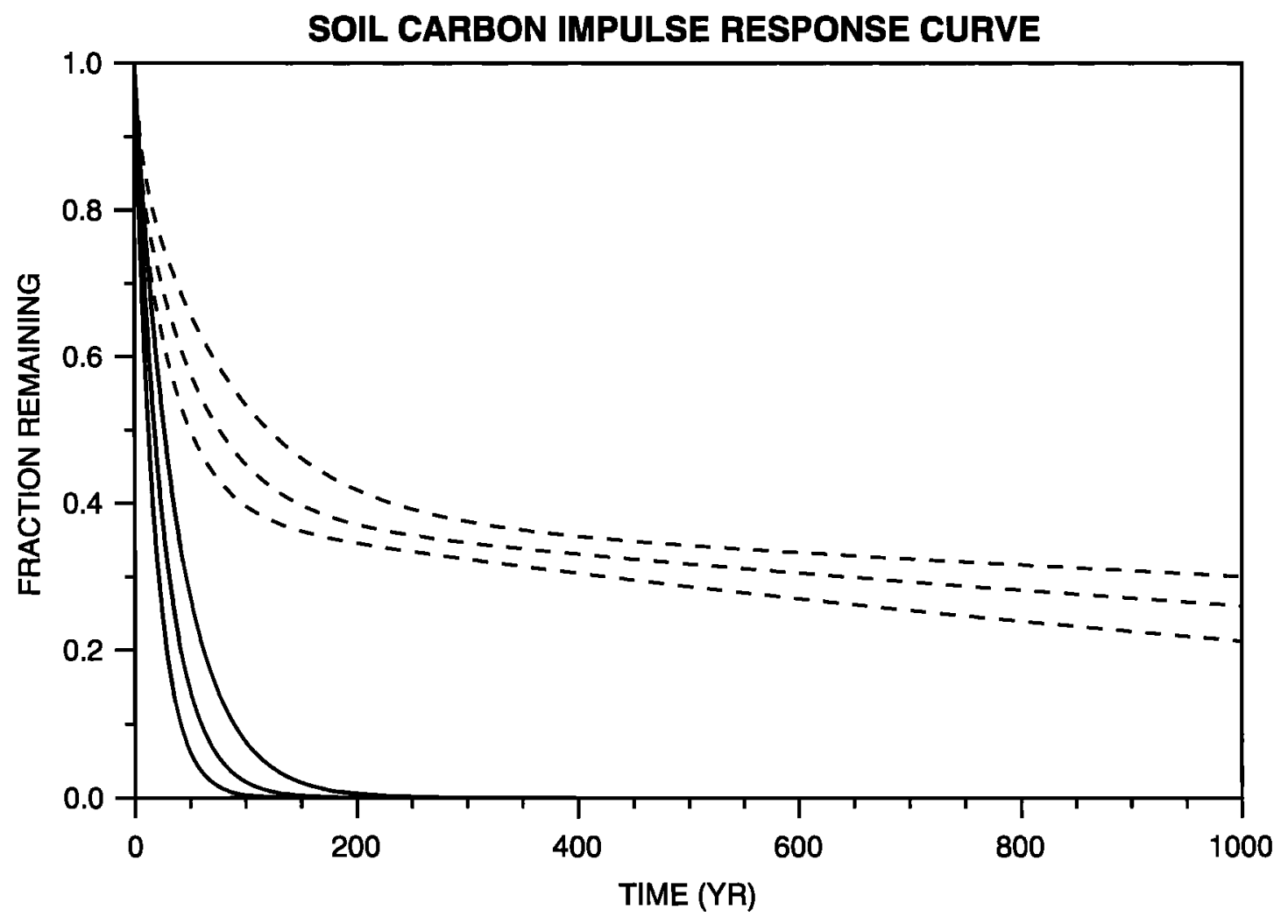

Figure 6. Zonal decay responses, with inputs set to zero, of Century soil organic matter compartments using the full model (dashed lines) and a one-pool approximation (solid lines). The three lines for each model correspond to the MAT zones of Figure 4, with decay constants estimated as in Figure 6. Note that for both models the decay is fastest in tropical soils, slowest in high-latitude soils, and intermediate in the temperate zone. 
Table 4a. Lignin to Nitrogen Ratios and Percent Structural Carbon (Lignin Plus Cellulose) for Peatland Soils

\begin{tabular}{lccc}
\hline Wetland Type & Depth, cm & L:N Ratio & $\begin{array}{c}\text { Structural } \\
\text { Carbon, \% }\end{array}$ \\
\hline \multirow{2}{*}{ Fen } & $0-10$ & 18 & 57 \\
& $10-20$ & 18.5 & 60 \\
Bog & $20-80$ & 18.5 & 59 \\
& $0-10$ & 28.5 & 57 \\
& $10-20$ & 25.5 & 60 \\
& $20-80$ & 50 & 62 \\
\hline
\end{tabular}

Table is adapted from Valentine et al., [1994].

under anaerobic conditions and can simulate nutrient impoverishment in anaerobic soils. The hydrology typical of wetlands, the dynamics of $\mathrm{pH}$ and $\mathrm{pH}$ effects, and effects of anaerobiosis on lignin decomposition [Benner et al., 1984] have not yet been incorporated into the model. Some significant questions about the mechanisms of decomposition under anaerobic conditions are unresolved [Lee, 1992]. However, a number of scenarios of global change suggest warming and drying of northern peatlands. On the basis of percent structural (lignin plus cellulose [Parton et al., 1994]) and nitrogen analyses by Valentine et al. [1994] for peats from the Hudson's Bay lowlands, we suggest that peats are largely composed of material similar to Century's surface structural litter $\mathbf{( 5 7 . 6 2 \%}$ of peat is lignin plus cellulose; see Table $4 \mathrm{a}$ ). The turnover time of the metabolic fraction of litter ( $-40 \%$ of total) is of the order of a few years or less, and so it would be decomposed within a decade or so following a change to aerobic conditions. Under aerobic conditions the turnover time of surface structural litter is $\sim 46$ years (13 to 66 years) at mean annual temperatures of $-4^{\circ}$ to $8.5^{\circ} \mathrm{C}$ (Table $4 \mathrm{~b}$ ), suggesting that if climate change results in drying of peats and conversion to aerobic metabolism, decomposition rates would be relatively rapid and the system could respond to changing microclimate in decades. Under this scenario, SOC in peatlands would be considerably less stable than SOC stored in mineral soils. This is particularly true if warming is coupled with changes in hydrology. Changes due to temperature could be amplified if the "surface" $20 \mathrm{~cm}$ sinks as a result of a dropping water table. This effect may have already been observed by Oechel et al. [1993].

Table 4b. Turnover Times of Aerobic Surface Structural Detritus (Lignin plus Cellulose), Estimated by Century Model.

\begin{tabular}{lcc}
\hline Site & $\begin{array}{c}\text { MAT, } \\
{ }^{\circ} \mathrm{C}\end{array}$ & $\begin{array}{c}\text { Turnover Time, } \\
\text { Years }\end{array}$ \\
\hline Tuva & 3.4 & 66 \\
Shortandy & 1.4 & 41 \\
Otradnoye & 4.0 & 67 \\
Kursk & 5.5 & 13 \\
Sidney & 8.5 & 44 \\
\hline
\end{tabular}

MAT is mean annual temperature.

\section{Depth Considerations}

Century simulates organic carbon dynamics of the upper 20 $\mathrm{cm}$ of soil, a depth which normally contains about $35-50 \%$ of the $1 \mathrm{~m}$ inventory [Parton et al., 1987; Schimel et al., 1985; Yonker et al., 1988; Brown and Lugo, 1990]. The $20 \mathrm{~cm}$ depth was chosen because of decreasing $\mathrm{C}$ and $\mathrm{N}$ mineralization rates [Schimel and Parton, 1986] and increasing isotopic turnover times occurring with depth [Scharpenseel and Becker-Heidmann, 1992; Harrison et al., 1993]. Most of the "actively cycling" C and $\mathrm{N}$ is found in the top soil layers [e.g., Harrison et al., 1993; Scharpenseel and Becker-Heidmann, 1992], although the depth of the active layer and its variability with climate and other factors are very uncertain. A key research issue is to develop a basis for modeling SOC turnover as a function of depth rather than modeling SOC turnover within a single layer [Veldkamp. 1993]. Given the results shown in Figure 6, it seems crucial to separate the millennial timescale $S O C$ at depth from the actively cycling surface pools. Processes governing $\mathrm{C}$ and $\mathrm{N}$ accumulation and potential losses at depth are poorly understood [Parton et al., 1994]. As noted by Harden et al. [1992], turnover of $\mathbf{C}$ for the whole soil is of the order of millenia, and residence times of 4000-8000 years are common in deeper soil layers [Yonker et al., 1988].

While differences in the depth increment between models may explain some of the differences between models in Table 3, the SOC at depth is largely passive and should not respond dynamically to environmental changes (except, possibly, in deep tropical soils (S.E. Trumbore, personal communication, 1994)).

\section{Conclusions}

Globally, rates of soil carbon turnover vary widely, with turnover times significantly shorter in tropical than in highlatitude soils. While variations in total SOC turnover times are significant, variations within specific detrital and soil organic matter fractions are even more dramatic; for example, slow SOC turnover ranges from -10 to $>100$ years. While simpler models [Townsend et al., 1992; Melillo et al., 1993] can produce the same steady state as Century, transient simulations require consideration of the multiple timescales of response inherent in the soil system (Figures 4 and 6) [Parton et al., 1994; Jenkinson et al., 1991].

The similar effects of temperature, soil texture, and lignin content on SOC storage $\left(1000-6000 \mathrm{~g} \mathrm{~m}^{-2}\right.$ over the ranges of lignin, temperature, and clay content simulated) suggest that in global simulations, climatic, edaphic, and biotic factors are all important as controls. This study did not address variations due to soil moisture changes, which are more complex. While across a limited domain, one factor may appear to dominate (e.g., temperature in the U.S. Great Plains [Jenny, 1980; Schimel et al., 1990]), global models must be multifactorial. This conceptual view of controls over SOC accumulation was originally proposed by Jenny [1941]; our model implements and quantifies a subset of Jenny's conceptual equations. Specifically, while soil carbon storage is controlled, in part, by geochemical interactions with climate and soil minerals, it is also linked to plant community composition and physiology through detrital chemistry (and other factors, such as allocation patterns [Holland et al., 1992]). Climate change and direct human effects on vegetation distributions will likely have an equal or larger influence than 
direct effects of temperature on soil carbon at affected locations based on our sensitivity analyses to changing lignin. Movement of climatic boundaries between ecosystems whose life-forms have substantially different lignin contents, such as at forestgrassland or tundra-taiga transitions, could significantly affect soil $\mathrm{C}$, as could human-induced conversions of forests to pastures or grasslands to woodlands. Changing atmospheric $\mathrm{CO}_{2}$ could also influence SOC storage and temperature sensitivity. Ecosystem models including Century [Schimel et al., 1990; Ojima et al., 1993], OMB [Esser, 1990] and TEM [Melillo et al., 1993] all suggest that increasing $\mathrm{CO}_{2}$ will reduce the effect of warming on carbon stores because increasing $\mathrm{CO}_{2}$ increases $\mathrm{C}$ inputs and widens detrital $\mathrm{C}: \mathrm{N}$ ratios, retarding decomposition.

The $\mathbf{N}$ cycle appears to be crucial to understanding the temperature response of ecosystems [Schimel et al., 1990]. In Century, as decomposition increases with warmer temperatures, $\mathbf{N}$ cycles more rapidly. As soil organic matter is lost, more $\mathbf{N}$ becomes available for plant growth, which results in more soil organic matter formation, acting as a negative feedback. The nitrogen feedback which moderates SOC temperature sensitivity can be described by the following, as production minus decomposition:

$$
\frac{d \mathrm{SOC}}{d t}=\left[\frac{\partial \mathrm{NPP}}{\partial T}+\left(\frac{\partial \mathrm{N}_{\min }}{\partial T}[1-L]\right) \mathrm{C}: \mathrm{N}\right] d T-\left[\frac{\partial \mathrm{NPP}}{\partial T}\right] d T
$$

where $\partial \mathrm{N}_{\operatorname{mid}} / \partial T$ is the release of $\mathrm{N}$ associated with SOM loss from warming, $L$ the fractional loss of that $\mathrm{N}$ to trace gases and leaching, and $\mathrm{C}: \mathrm{N}$ the carbon to nitrogen ratio of incremental biomass produced using the released $N$. The last term, $\partial N P P / \partial T$, is the effect of temperature on decomposition summed over all pools, each containing a fraction $w_{l}$ of total SOC, with decay constants $k_{i}$ (as in (8)). In this formulation, considerably simplified from the actual mechanisms in Century, climatic and chemical forcing of the atmospheric and hydrologic systems associated with outputs produced via $L$ must also be considered as part of the environmental impact of warming.

When the $\mathbf{N}$ cycle feedback was artificially eliminated from Century by fixing NPP levels at current levels in simulation experiments, losses of SOC doubled. A similar difference in sensitivity exists between Century $\left(-11.1 \mathrm{Pg}^{\circ} \mathrm{C}^{-1}\right)$ and CASA ($21.5 \mathrm{Pg}^{\circ} \mathrm{C}^{-1}$ ), which simulate decomposition with broadly similar algorithms. However, in CASA, NPP is fixed by satellite measurements and does not respond to increasing $N$ mineralization rates. If biomass is removed by crop or forest harvesting, burning or herbivory, or where NPP is restricted by some other effect (e.g., ozone [Reich, 1987]), the nutrient feedback may, in reality, be weakened and SOC losses could accelerate. The contrast between the positive and negative nutrient feedback model experiments suggests that a simple representation of the $\mathbf{N}$ cycle is essential for even first-order calculations.

Acknowledgments. This paper is dedicated to the late Hans Jenny. Primary support for this research was provided by a NASA Interdisciplinary Program award to E.A.H., and by NASA's EOS Program through an EOS Interdisciplinary Science grant to D.S.S. Additional support was provided by the Climate System Modeling Program of UCAR, supported by NSF and DOE, and by the Oak Ridge Associated Universities Fellowships for Global Change (to B.H.B.). The authors gratefully acknowledge the participants and leadership of the SCOPE project on Primary Production and Decomposition in Temperate Forests and Grasslands, whose collective efforts provided much of the information required in this analysis. Pierre Friedlingstein provided unpublished results of a temperature perturbation experiment using his model. Chris Potter, Jim Randerson, Chris Field and colleagues calculated the $1^{\circ} \mathrm{C}$ sensitivity of CASA, and we appreciate their permission to use their results in this report and elsewhere. Tim Kittel suggested calculating the effects of warming with uncoupled NPP. We thank Sue Trumbore, Cindy Nevison, Inez Fung, Ralph Keeling, Elaine Matthews and Pieter Tans for helpful discussion, information, and insight. Reviews by Sue Trumbore, Jennifer Harden, Phil Sollins, Bill Schlesinger and the critical eye of Elizabeth Sulzman were important to improving the manuscript. The National Center for Atmospheric Research is sponsored by the National Science Foundation.

\section{References}

Becker-Heidmann, P., and H.-W. Scharpenseel, The use of natural ${ }^{14} \mathrm{C}$ and ${ }^{13} \mathrm{C}$ in soils for studies on global climate change, Radiocarbor, 34 , 535-540, 1992.

Benner, R., S.Y. Newell, A.E. Maccubbin, and R.E. Hodson, Relative contributions of bacteria and fungi to rates of degradation of lignocellulosic detritus in salt-marsh sediments, Appl. Environ. Microbiol., 48, 36-40, 1984.

Brown, S., and A.E. Lugo, Effects of forest clearing and succession on the carbon and nitrogen content of soils in Puerto Rico and US Virgin Islands, Plant Soil, 124, 53-64, 1990.

Buol, S.W., P.A. Sanchez, J.M. Kimble, and S.B. Weed, Predicted impact of climate warming on soil properties and use, in Impect of Carbon Dioxide, Trace Gases, and Climate Change on Global Agriculture, edited by B.A. Kimball et al., ASA Spec. Publ., 53, 71-82, 1990.

Burke, I.C., C.M. Yonker, W.J. Parton, C.V. Cole, K. Flach, and D.S. Schimel, Texture, climate, and cultivation effects on soil organic matter content in U.S. grassland soils, Soil Sci. Soc. Am. J., 53, 800$805,1989$.

Ciais, P., P. Tans, J.W. White, R. Francey, M. Trolier, J. Berry, D. Berry, D. Randall, P. Sellers, and D. Schimel, submitted: The global carbon budget inferred form a new worldwide data set of $8^{13} \mathrm{C}$ measurements in atmospheric $\mathrm{CO}_{2}$.Joumal of Geophysical Research-Atmospheres.

Comins, H.N., and R.E. McMurtrie, Long-term biotic response of nutrient-limited forest ecosystems to $\mathrm{CO}_{2}$-enrichment: Equilibrium behaviour of integrated plant-soil models, Ecol. Appl., 3, 666-681, 1993.

Davidson, E.A., and I.L. Ackerman, Changes in soil carbon inventories following cultivation of previously untilled soils, Biogeochemistry, 20, 161-194, 1993.

Esser, G., Modeling global terrestrial sources and sinks of $\mathrm{CO}_{2}$ with special reference to soil organic matter, in Soils and the Greenhouse Effect, edited by A.F. Bouwman, pp. 247-262, John Wiley, New York, 1990.

Eswaran, H., E. Van den Berg, and P. Reich, Organic carbon in soils of the world, Soil Sci. Soc. Am. J., 57, 192-194, 1993.

Friedlingstein, P., C. Delire, and J.F. Muller, The climate induced variation of the continental biosphere: A model simulation of the last glacial maximum, Geophys. Res. Lett., 19, 897-900, 1992.

Gregorich, E.G., R.P. Voroney, R.G. Kachanoski, Turnover of carbon through the microbial biomass in soils with different textures, Soil Biol. Biochem., 23, 799-805, 1991.

Harden, J.W., E.T. Sundquist, R.F. Stallard, and R.K. Mark, Dynamics of soil carbon during deglaciation of the Laurentide ice sheet, Science, 258, 1921-1924, 1992.

Harrison, K., W. Broecker, and G. Bonani, A strategy for estimating the impact of $\mathrm{CO}_{2}$ fertilization on soil carbon storage, Global Biogeochem. Cycles, 7, 69-80, 1993.

Holland, E.A., W.J. Parton, J.K., Detling, and D.L. Coppock, 
Physiological responses of plant populations to herbivory and their consequences for ecosystem nutrient flow, Am. Nat., 140, 685-706, 1992.

Houghton, R.A., and G.M. Woodwell, Global climatic change, Sci. Am., 260, 4, 36-47, 1989.

Jenkinson, D.S., and J.H. Raynor, The turnover of soil organic matter in some of the Rothamsted classical experiments, Soil Sci., 123, 298-305, 1977.

Jenkinson, D.S., D.E. Adams, and A. Wild, Model estimates of $\mathrm{CO}_{2}$ emissions from soil in response to global warming, Nature, 351, 304 306, 1991.

Jenny, H., Factors of Soil Formation, McGraw-Hill, New York, 1941.

Jenny, H., The Soil Resource, Ecol. Stud. vol. 37, Springer-Verlag, New York, 1980.

Juma, N.G., Interrelationships between soil structure/texture, soil biota/soil organic matter and crop production, Geoderma, 57, 3-30, 1993.

Lee, C., Controls on organic carbon preservation: The use of stratified water bodies to compare intrinsic rates of decomposition in oxic and anoxic systems, Geochim. Cosmochim. Acta, 56, 3323-3336, 1992.

Legates, D.R., and C.J. Willmott, Mean seasonal and spatial variability in global surface air temperature, Theor. Appl. Climatol., 41, 11-21, 1990.

McGuire, A.D., J.M. Melillo, L.A. Joyce, D.W. Kicklighter, A.L. Grace, B. Moore III, and C.J. Vorosmarty, Interactions between carbon and nitrogen dynamics in estimating net primary productivity for potential vegetation in North America, Global Biogeochem. Cycles, 6, 101-124, 1992.

Melillo, J.M., A.D. McGuire, D.W. Kicklighter, B. Moore III, C.J. Vorosmarty, and A.L. Schloss, Climate change and terrestrial net primary production, Nature, 363, 234-240, 1993.

Melillo, J.M., D.W. Kicklighter, A.D. McGuire, W.T. Peterjohn, and K. Newkirk, Global change and its effects on soil organic carbon stocks, in Global Changes in the Perspective of the Past, edited by J.A. Eddy and H. Oeschger, John Wiley and Sons, Ghichester, in press, 1994.

Nadlehoffer, K.J., F.D. Hole, and G.A. Nielsen, Recovery of organic matter stocks and fertility following experimental impoverishment on temperate forest soils, Agron. Abstr., S-7, 250, 1987.

Oechel, W.C., S.J. Hastings, G. Vourlitis, M. Jenkins, G. Riechers, and N. Grulke, Recent change of Arctic tundra ecosystems from a net carbon dioxide sink to a source, Nature, 361, 520-523, 1993.

Ojima, D.S., W.J. Parton, D.S. Schimel, J.M.O. Scurlock, and T.G.F. Kittel, Modeling the effects of climatic and $\mathrm{CO}_{2}$ changes on grassland storage of soil C, Water Air Soil Pollut., 70, 643-657, 1993.

Parton, W.J., D.S. Schimel, C.V. Cole, and D.S. Ojima, Analysis of factors controlling soil organic matter levels in Great Plains grasslands, Soil Sci. Soc. Am. J., 51, 1173-1179, 1987.

Parton, W.J., et al., Observations and modeling of biomass and soil organic matter dynamics for the grassland biome worldwide, Global Biogeochem. Cycles, 7, 785-809, 1993.

Parton, W.J., D.S. Schimel, D.S. Ojima, and C.V. Cole, A general model for soil organic matter dynamics: Sensitivity to litter chemistry, texture and management, in Quantitative Modeling of Soil Forming Processes, edited by R.B. Bryant, Soil Sci. Soc. Am. J., in press, 1994.

Pastor, J., and W.M. Post, Influence of climate, soil moisture, and succession of forest carbon and nitrogen cycles, Biogeochemistry, 2, 327, 1986.

Paustian, K., O. Andren, M. Clarholm, A.-C. Hansson, G. Johansson, and J. Lagerlof, Carbon and nitrogen budgets for four agro-ecosystems with annual and perennial crops with and without $\mathbf{N}$ fertilization, $J$. Appl. Ecol., 27, 60-84, 1990.

Peterjohn, W.T., J.M. Melillo, F.P. Bowles, and P.A. Steudler, Soil warming and trace gas fluxes: Experimental design and preliminary flux results, Oecologia, 93, 18-24, 1993.

Post, W.M., J. Pastor, P.J. Zinke, and A.G. Stangenberger, Global patterns of soil nitrogen storage, Nature, 317, 613-616, 1985.

Potter C.S., J.T Randerson, C.B. Field, P.A. Matson, P.M. Vitousek, H.A.
Mooney, and S.A. Klooster, Terrestrial ecosystem production: A process model based on global satellite and surface data, Global Biogeochem. Cycles, 7, 811-841, 1993.

Quay, P.D., B. Tilbrook, and C.S. Wong, Oceanic uptake of fossil fuel $\mathrm{CO}_{2}$ : Carbon-13 evidence, Science, 256, 74-79, 1992.

Raich, J.W., and W.H. Schlesinger, The global carbon dioxide flux in soil respiration and its relationship to vegetation and climate, Tellus, Ser. $B, 44,81-99,1992$.

Reich, P.B., Quantifying plant response to ozone: A unifying theory, Tree Physiol., 3, 63-91, 1987.

Scharpenseel, H.W., and P. Becker-Heidmann, Twenty-five years of radiocarbon dating soils: Paradigm of erring and learning, Radiocarbon, 34, 541-549, 1992.

Schimel, D.S., Carbon and nitrogen turnover in adjacent grassland and cropland ecosystems, Biogeochemistry, 6, 239-243, 1986.

Schimel, D.S., and W.J. Parton, Microclimatic controls of nitrogen mineralization and nitrification in shortgrass steppe soils, Plant Soil, 93, 347-357, 1986.

Schimel, D.S., D.C. Coleman, and K.A. Horton, Soil organic matter dynamics in paired rangeland and cropland toposequences in North Dakota, Geoderma, 36, 201-214, 1985.

Schimel, D.S., W.J. Parton, T.G.F. Kittel, D.S. Ojima, and C.V. Cole, Grassland biogeochemistry: Links to atmospheric processes, Clim Change, 17, 13-25, 1990.

Schimel, D.S., T.G.F. Kittel, and W.J. Parton, Terrestrial biogeochemical cycles: Global interactions with the atmosphere and hydrology, Tellus, Spec. Issue AB, 43, 188-203, 1991 a.

Schimel, D.S., T.G.F. Kittel, A.K. Knapp, T.R. Seastedt, W.J. Parton, and V.B. Brown, Physiological interactions along resource gradients in a tallgrass prairie, Ecology, 72, 672-684, 1991 b.

Schlesinger, W.H., Carbon balance in terrestrial detritus, A. Rev.Ecol. Syst., 8, 51-81, 1977.

Schlesinger, W.H., Evidence from chronosequence studies for a low carbon-storage potential of soils, Nature, 348, 232-234, 1990.

Sellers, P.J., J.A. Berry, G.J. Collatz, C.B. Field, and F.G. Hall, Canopy reflectance, photosynthesis, and transpiration; III, A reanalysis using improved leaf models and a new canopy integration scheme, Remote Sens. Environ., 42, 187-216, 1992.

Shaver, G.R., W.D. Billings, F.S. Chapin, A.E. Giblin, K.J. Nadlehoffer, W.C. Oechel, and E.B. Rastetter, Global change and the carbon balance of Arctic ecosystems, BioScience, 42, 433-441, 1992.

Smith, T.M., and H.H. Shugart, The transient response of terrestrial carbon storage to a perturbed climate, Nature, 361, 523-526, 1993.

Stuiver, M., R.L. Burk, and P.D. Quay, Carbon-13/carbon-12 ratios in tree rings and the transfer of biospheric carbon to the atmosphere, $J$. Geophys. Res., 89, 11,731-11,748, 1984.

Tans, P.P., I.Y. Fung, and T. Takahashi, Observational constraints on the global atmospheric $\mathrm{CO}_{2}$ budget, Science, 247, 1431-1438, 1990.

Tans, P.P., J.A. Berry, and R.F. Keeling, Oceanic ${ }^{13} \mathrm{C}^{12} \mathrm{C}$ observations: A new window on ocean $\mathrm{CO}_{2}$ uptake, Global Biogeochem. Cycles, 7 , 353-368, 1993.

Townsend, A.R., The effect of temperature and land use on soil carbon storage in forest ecosystems of Hawaii, Ph.D. dissertation, Dep. of Biol., Stanford Univ., Stanford, Calif., 1993.

Townsend, A.R., P.M. Vitousek, and E.A. Holland, Tropical soils could dominate the short-term carbon cycle feedbacks to increased global temperatures, Clim. Change, 22, 293-303, 1992.

Trumbore, S.E., Comparison of carbon dynamics in tropical and temperate soils using radiocarbon measurements, Global Biogeochem. Cycles, 7, 275-290, 1993.

Trumbore, S.E., G. Bonani, and W. Wölfli, The rates of carbon cycling in several soils from AMS ${ }^{14} \mathrm{C}$ measurements of fractionated soil organic matter, in Soils and the Greenhouse Effect, edited by A.F. Bouwman, pp. 405-414, John Wiley, New York, 1990.

Valentine, D., E.A. Holland, and D.S. Schimel, Ecological and physiological controls over methanogenesis in boreal wetlands, $J$. Geophys. Res., 99, 1563-1571, 1994. 
Veldkamp, E., Soil organic carbon dynamics in pastures established after deforestation in the humid tropics of Costa Rica, Ph.D. dissertation, Dep. of Soil Sci. and Geol., Wagenigen Agric. Univ., Wagenigen, Netherlands, 1993.

Vitousek, P.M., and R.W. Howarth, Nitrogen limitation on land and in the sea: How can it occur?, Biogeochemistry, 13, 87-115, 1991.

Webb, R.S., C.E. Rosenzweig, and E.R. Levine, Specifying land surface characteristics in general circulation models: Soil profile data set and derived water-holding capacities, Global Biogeochem. Cycles, 7, 97 $108,1993$.

Wofsy, S.C., M.L. Goulden, J.W. Munger, S.-M. Fan, P.S. Bakwin, B.C. Daube, S.L. Bassow, and F.A. Bazzaz, Net exchange of $\mathrm{CO}_{2}$ in a midlatitude forest, Science, 260, 1314-1317, 1993.

Yonker, C.M., D.S. Schimel, E. Paroussis, and R.D. Heil, Patterns of organic carbon accumulation in a semiarid shortgrass steppe, Soil Sci. Soc. Am. J., 52, 478-483, 1988.
Zobler, L., A world soil file for global climate modeling, NASA Tech. Mem., 87802, 1986.

B.H. Braswell, Institute for the Study of Earth, Oceans, and Space, University of New Hampshire, Durham, NH 03824.

E.A. Holland, R. McKeown, T.H. Painter, and D.S. Schimel, National Center for Atmospheric Research, P.O. Box 3000, Boulder, CO 80307.

D.S. Ojima and W.J. Parton, Natural Resource Ecology Laboratory, Colorado State University, Fort Collins, CO 80523.

A.R. Townsend, Department of Biology, Stanford University, Stanford, CA 94305.

(Received January 5, 1994; revised April 1, 1994; accepted April 11, 1994.) 